\title{
A Snapshot of the Prevalence and Molecular Diversity of Legionella pneumophila in the Water Systems of Israeli Hotels
}

\author{
Eugenia Yakunin ${ }^{1}$, Eszter Kostyal ${ }^{2}$, Vered Agmon ${ }^{1}$, Itamar Grotto ${ }^{1,3}$, Lea Valinsky ${ }^{1}$ and \\ Jacob Moran-Gilad 1,3,* \\ 1 Central Laboratories and Public Health Services, Ministry of Health, Jerusalem 9134302, Israel; \\ eugenia.yakunin@moh.gov.il (E.Y.); vered.agmon@moh.gov.il (V.A.); itamar.grotto@moh.gov.il (I.G.); \\ lea.valinsky@moh.gov.il (L.V.) \\ 2 Department of Water Microbiology, Biolab Ltd., Jerusalem 9134001, Israel; ester@biolab-chemicals.com \\ 3 Department of Health Systems Management, School of Public Health, Faculty of Health Sciences, \\ Ben-Gurion University of the Negev, Beer-Sheva 8410501, Israel \\ * Correspondence: giladko@post.bgu.ac.il
}

Received: 20 April 2020; Accepted: 23 May 2020; Published: 27 May 2020

\begin{abstract}
Exposure to Legionella spp. contaminated aerosols in hotel settings confers risk for travel-associated Legionnaire's disease (TALD). In this study, we investigated the prevalence of Legionella contamination and its molecular diversity in hotels and resorts across Israel. The study was comprised of a convenience sample of water systems from 168 hotels and resorts countrywide, routinely inspected between March 2015 and February 2017. Isolation and quantitation of Legionella were performed in a water laboratory using the ISO 11731 method. The distribution of Legionella isolates was analyzed according to geography and source. The genetic diversity of a subset of isolates was analyzed by sequence-based typing (SBT) at the National Reference Laboratory for Legionella and compared to the national database. Out of 2830 samples tested, 470 (17\%) obtained from 102 different premises (60\% of hotels) were positive for Legionella spp. In 230 samples (49\% of all positive, $8 \%$ of total samples), accounting for $37 \%$ of hotels, Legionella spp. counts exceeded the regulatory threshold of $1000 \mathrm{CFU} / \mathrm{L}$. The most frequently contaminated water sources were cooling towers (38\%), followed by faucets, hot tubs, water lines, and storage tanks (14-17\% each). Furthermore, 32\% and 17\% of samples obtained from cooling towers and hot tubs, respectively, exceeded the regulatory thresholds. SBT was performed on 78 strains and revealed 27 different sequence types (STs), including two novel STs. The most prevalent STs found were ST1 (26\%), ST87 (10\%), ST93 (6\%), and ST461 and ST1516 (5\% each). Several L. pneumophila STs were found to be limited to certain geographical regions. This is the first study to investigate the prevalence and diversity of Legionella in hotels and resorts in Israel during non-outbreak environmental inspections. These findings will inform risk assessment, surveillance, and control measures of TALD.
\end{abstract}

Keywords: Legionella pneumophila; SBT; molecular diversity; hotels

\section{Introduction}

Legionella is a Gram-negative bacterium found ubiquitously in aqueous environments, which can multiply quickly in man-made water systems [1]. Legionella spp. have a complex life cycle, and exist in the environment as free-living bacteria in microbial consortia of environmental organisms or as intracellular pathogens. L. pneumophila has plenty of virulence factors, which it uses effectively to infect aquatic protozoa or human lung alveolar macrophages [2]. 
L. pneumophila is the major causative agent of Legionnaires' disease (LD), a severe pneumonia with a fatality rate of up to $15 \%$, and a flu-like illness called Pontiac fever [3,4]. Humans can contract the disease during exposure to contaminated water aerosols generated by hot and cold water systems, cooling towers, showering facilities, and spa pools [5]. Legionella bacteria is an opportunistic pathogen [2]. The risk factors include old age, underlying diseases, and smoking [6]. Although many Legionella spp. are considered potentially pathogenic for humans, Legionella pneumophila (Lp) causes the vast majority of LD cases, and of the 16 known Lp serogroups (sg), $\mathrm{sg} 1$ accounts for over $80 \%$ of LD cases $[7,8]$.

Legionellosis is often associated with staying in hotel accommodations, and LD is recognized as a major form of travel-associated pneumonia (TALD) [9]. Since 2010, TALD cases have accounted for $20 \%$ of all reported LD cases in Europe each year. The number of cases reported to the European TALD surveillance scheme continues to rise annually, with a 20\% increase observed between 2014 and 2015 [10]. Moreover, Legionella pneumophila has significant outbreak potential. Since its first fatal outbreak in a hotel in Philadelphia, United States, in 1976, many clusters and outbreaks linked to hotel settings have been investigated globally [11-14]. Factors shown to contribute to the Legionella spp. spread and colonization are the complexity, old age, and poor maintenance of a distribution system, warm water temperature, and the presence of amoebae [1,15-17]. Several recent studies have focused on the prevalence and distribution of Legionella in water systems of hotels in non-outbreak situations. These studies revealed variable rates of contamination and species diversity [18-21], but limited data is published on the molecular diversity of Legionella spp. in hotel settings [22-24].

In Israel, where international and domestic tourism is an important branch of the national economy, TALD has accounted for 15\% of all LD cases between 2006 and 2011 [25]. According to recent national epidemiology surveillance data of the Ministry of Health, the majority of TALD cases in Israel are sporadic or imported from abroad, and no major change in trends was observed during the last decade. While isolates from TALD cases undergo molecular typing, a few of them have been linked to a specific accommodation sites. It is likely that a great proportion of cases go unnoticed, due to the mild symptoms and underdiagnosis, the long incubation period of Legionella spp., and the short-term nature of domestic tourism. Of note is that no comprehensive data are available concerning the abundance of Legionella spp. in Israeli hotel water systems. In this study, we investigated, for the first time, the prevalence and characteristics of environmental Legionella spp. in the Israeli hotel setting as part of routine inspections.

\section{Results}

\subsection{Legionella Contamination Rates}

During the study period, 2830 water specimens were collected routinely from the water systems of 168 hotels and resorts in six districts across Israel. Legionella spp. were isolated from 470 samples $(17 \%)$ originating from $102(60 \%)$ hotels. The percentage of Legionella-positive samples was lower in the Southern, Jerusalem, and Tel Aviv districts (13\%, 15\%, and 14\%, respectively), of which the largest number of samples was submitted (1139, 794, and 447 samples). A higher level of contamination was found in the North $(40 \%)$, but only 42 samples were collected (Table 1 and Figure 1). In 230 samples ( $49 \%$ of all positive, $8 \%$ of total samples), accounting for $37 \%$ of hotels, Legionella spp. concentrations exceeded the national regulatory thresholds. The percentage of exceeding samples per district ranged from $6 \%$ to $33 \%$ (Table 1 ).

Analysis of Legionella spp. prevalence according to sample source showed that both cold and hot water distribution systems were colonized. The leading contaminated water sources were cooling towers ( $38 \%)$, followed by hot tubs, outlets, and main water lines (14-17\% each). Of 277 Legionella-positive water samples from the outlets representing hotel rooms, $166(59.9 \%)$ and $111(40.1 \%)$ were from hot and cold water systems, respectively. The respective positivity rates were $15.3 \%$ and $17.1 \%$. Levels exceeding regulatory Legionella counts were detected in 84 samples from the outlets, of 
which 67 samples $(79.7 \%)$ originated from hot and $17(20.2 \%)$ from cold water systems. The respective exceedance rates above regulatory thresholds were $6.2 \%$ and $2.6 \%$. The majority of contaminated main water lines represented hot water distribution systems and accounted for $63(92.6 \%)$ of 68 positive samples from water lines. Only five (7.3\%) positive samples were from cold water lines. Of 35 samples with levels of contamination exceeding regulatory thresholds, $33(94.2 \%)$ were from hot water lines at a rate of $8.6 \%$. In $74(32 \%)$ of 232 samples from cooling towers, and $36(17 \%)$ of 218 samples from hot tubs, levels of Legionella spp. exceeded the regulatory thresholds of $1000 \mathrm{CFU} / \mathrm{L}$ established for potable water and the $1 \mathrm{CFU} / 100 \mathrm{~mL}$ threshold for the hot tubs (Table 2).

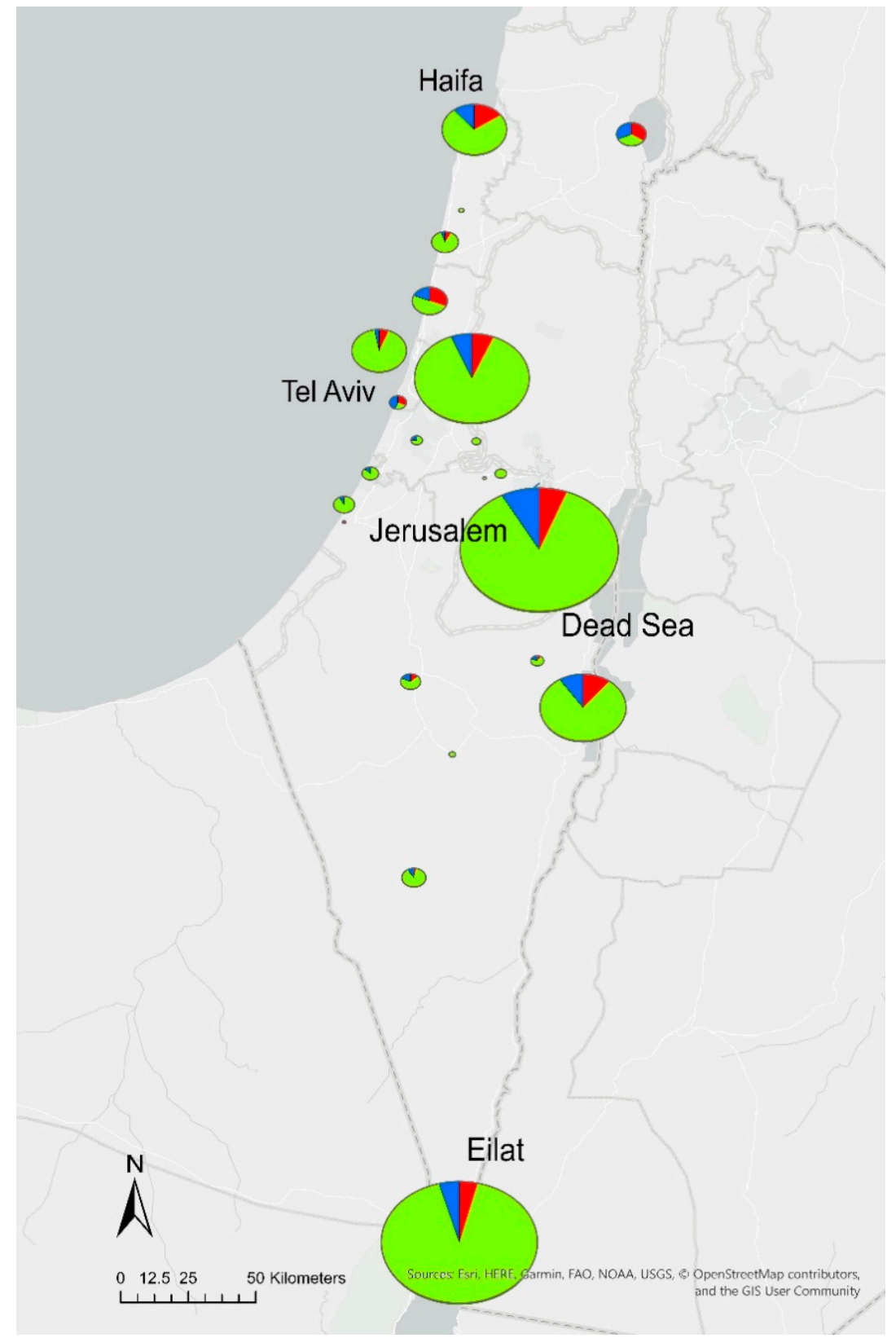

Figure 1. Geographic distribution and number of samples obtained from the 168 hotels and resorts included in the study. Samples are represented as pie charts at different locations; the size is proportional to the number of samples obtained from a specific location. Negative samples are shown in green, and positive and exceeding samples are shown in blue and red, respectively. Four major tourist sites with the largest number of samples (negative/positive/exceeding the regulatory thresholds) are Eilat (695/38/34), Jerusalem (662/71/52), the Tel-Aviv region (384/31/32) and the Dead Sea region (210/28/32). 
Table 1. Distribution of premises and samples, according to administrative region.

\begin{tabular}{ccccccc}
\hline \multirow{2}{*}{ District } & \multicolumn{2}{c}{ Total Tested } & \multicolumn{2}{c}{ Positive Samples } & \multicolumn{2}{c}{ Exceeding Samples $\mathbf{1}^{\mathbf{1}}$} \\
\cline { 2 - 7 } & $\begin{array}{c}\text { No. of } \\
\text { Hotels }\end{array}$ & $\begin{array}{c}\text { No. of } \\
\text { Samples }\end{array}$ & $\begin{array}{c}\text { No. of } \\
\text { Hotels }\end{array}$ & $\begin{array}{c}\text { No. of Samples } \\
\text { (\% Per District) }\end{array}$ & $\begin{array}{c}\text { No. of } \\
\text { Hotels }\end{array}$ & $\begin{array}{c}\text { No. of Samples } \\
\text { (\% Per District) }\end{array}$ \\
\hline North & 3 & 42 & 2 & $27(64)$ & 1 & $14(33)$ \\
Center & 9 & 207 & 6 & $54(26)$ & 4 & $30(14)$ \\
South & 78 & 1139 & 44 & $151(13)$ & 28 & $72(6)$ \\
Haifa & 9 & 201 & 7 & $52(26)$ & 4 & $30(15)$ \\
Tel Aviv & 20 & 447 & 12 & $63(14)$ & 8 & $32(7)$ \\
Jerusalem & 49 & 794 & 30 & $123(15)$ & 17 & $52(7)$ \\
\hline Total & $\mathbf{1 6 8}^{\text {a }}$ & $\mathbf{2 8 3 0}$ & $\mathbf{1 0 1}^{\mathbf{b}}$ & $\mathbf{4 7 0 ( 1 7 )}$ & $\mathbf{6 2}^{\mathbf{c}}$ & $\mathbf{2 3 0 ( 8 )}$
\end{tabular}

${ }^{1}$ Cut-off values of $1000 \mathrm{CFU} / \mathrm{L}$ for all categories and $1 \mathrm{CFU} / 100 \mathrm{~mL}$ for hot tubs, according to the national regulations; ${ }^{a}$ Out of 168 hotels and resorts tested for Legionella spp., 119 were tested more than once (range of 1-25 sampling days, median 2); ${ }^{b}$ Of 101 hotels with positive samples under the regulatory cutoffs, 56 were sampled at least twice (range of 1-17 sampling days, median 2); ${ }^{c}$ Of 62 hotels with Legionella concentrations above the national regulatory cutoffs, 29 were sampled at least twice (range of 1-12 sampling days, median 1).

Table 2. Prevalence of L. pneumophila, according to source type.

\begin{tabular}{|c|c|c|c|c|c|c|c|c|}
\hline \multirow{2}{*}{ Source Type } & \multicolumn{4}{|c|}{ No. of Samples } & \multicolumn{2}{|c|}{ Positive Samples } & \multicolumn{2}{|c|}{ Exceeding Samples ${ }^{1}$} \\
\hline & $\begin{array}{l}\text { Cold } \\
\text { Water }\end{array}$ & $\begin{array}{c}\text { Hot } \\
\text { Water }\end{array}$ & $\begin{array}{l}\text { Mixed } \\
\text { Water }^{2}\end{array}$ & Total & $\begin{array}{l}\text { No. of } \\
\text { Samples }\end{array}$ & $\begin{array}{c}\text { Per Category } \\
(\%)\end{array}$ & $\begin{array}{l}\text { No. of } \\
\text { Samples }\end{array}$ & $\begin{array}{c}\text { Per Category } \\
(\%)\end{array}$ \\
\hline Outlet & 649 & 1084 & & 1733 & 277 & $16 \%$ & 84 & $5 \%$ \\
\hline $\begin{array}{l}\text { Main water } \\
\text { line }\end{array}$ & 96 & 383 & & 479 & 68 & $14 \%$ & 35 & $7 \%$ \\
\hline Cooling tower & 232 & & & 232 & 87 & $38 \%$ & 74 & $32 \%$ \\
\hline Hot tub & 5 & 9 & 204 & 218 & 36 & $17 \%$ & 36 & $17 \%$ \\
\hline Fountain & 24 & 4 & & 28 & 1 & $4 \%$ & 0 & $0 \%$ \\
\hline Pool & 11 & & & 11 & 0 & $0 \%$ & 0 & $0 \%$ \\
\hline $\begin{array}{c}\text { Air } \\
\text { conditioning }\end{array}$ & 4 & & & 4 & 1 & $25 \%$ & 1 & $25 \%$ \\
\hline Not available ${ }^{3}$ & 38 & 87 & & 125 & 0 & $0 \%$ & 0 & $0 \%$ \\
\hline Total: & 1059 & 1567 & 204 & 2830 & 470 & $17 \%$ & 230 & $8 \%$ \\
\hline
\end{tabular}

${ }_{1}^{1}$ Cut off values of $1000 \mathrm{CFU} / \mathrm{L}$ for all categories and $1 \mathrm{CFU} / 100 \mathrm{~mL}$ for hot tubs, according to the national regulations; 2 According to the national regulations, the water temperature range of $37-39^{\circ} \mathrm{C}$ for hot tubs can be achieved by mixing hot and cold water. ${ }^{3}$ Source type not indicated in the laboratory requisition form accompanying the samples.

\subsection{Distribution of Serotypes}

Serotyping of a convenience sample comprised of 162 isolates revealed that 104 isolates (64\%) from 44 hotels belonged to sg2-14, and 53 (33\%) isolates from 22 hotels were sg1. Both sg1 and sg2-14 were found in the water systems of nine hotels. Two percent of isolates (4/162) for which serogroup identification failed and one recognized by the kit as Legionella spp. were subjected to mip sequencing, and subsequently identified as L. pneumophila and L. bozemanii, respectively. Overall, Lp accounted for the vast majority of the 162 serotyped isolates (99\%).

Furthermore, we analyzed serogroup prevalence according to sample type. The majority of sg2-14 isolates were recovered from hot and mixed water samples, and accounted for 81 (77.8\%) of the 104 isolates. Lp sg1 isolates were predominant in cold water systems, and $40(75.4 \%)$ of the 53 isolates originated from cold water.

\subsection{Phylogenetic Analysis}

Phylogenetic analysis using SBT of a subset of 78 isolates revealed 27 different STs, including two novel STs (ST2169, ST2284), with the index of diversity being 0.912 . Twelve STs were associated with more than one isolate, and 16 STs were identified with one single isolate. The most prevalent STs found were ST1 (26\%), ST87 (10\%), ST93 (6\%), and ST461 and ST1516 (5\% each). Of all Lp sg1 isolates, ST1 accounted for 63\% (20/32), while the leading Lp non-sg1 subtype, ST87, comprised $17 \%$ of all sg2-14 isolates (8/46). Amplification failure of the flaA fragment occurred in two allelic 
profiles $(0,4,16,1,7,13,206$ and $0,14,16,1,7,13,206)$, and therefore no STs could be obtained for them. The clustering analysis of the 27 strains is shown in Figure 2.

\begin{tabular}{|c|c|c|c|c|c|c|c|c|c|c|c|}
\hline \multicolumn{8}{|c|}{ Similarity, percentage } & \multirow[t]{2}{*}{ ST } & \multirow[t]{2}{*}{ Sg } & Source type & District \\
\hline 每 & $\Phi$ & $\frac{\underline{\bar{z}}}{2}$ & 奠 & है & 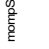 & 总 & 豪 & & & & \\
\hline & 7 & 6 & 17 & 3 & 13 & 11 & 11 & 59 & 1 & Faucet & Jerusalem \\
\hline & 7 & 6 & 17 & 3 & 13 & 11 & 11 & 59 & 1 & Faucet & Jerusalem \\
\hline & 7 & 6 & 17 & 3 & 13 & 11 & 11 & 59 & 1 & Hot tub & Jerusalem \\
\hline & 7 & 6 & 17 & 3 & 13 & 11 & 56 & 1979 & $2-14$ & Faucet & Haifa \\
\hline & 7 & 6 & 3 & 8 & 13 & 11 & 3 & 80 & $2-14$ & Faucet & Center \\
\hline & 8 & 6 & 34 & 9 & 53 & 8 & 209 & 1413 & $2-14$ & Storage tank & Haifa \\
\hline & 7 & 10 & 3 & 28 & 9 & 4 & 3 & 1641 & $2-14$ & Storage tank & Jerusalem \\
\hline & 7 & 10 & 3 & 28 & 9 & 4 & 3 & 1641 & $2-14$ & Faucet & Jerusalem \\
\hline & 7 & 10 & 3 & 28 & 9 & 4 & 3 & 1641 & 2-14 & Water line & Jerusalem \\
\hline & 2 & 10 & 3 & 28 & 9 & 4 & 13 & 87 & $2-14$ & Faucet & South \\
\hline & 2 & 10 & 3 & 28 & 9 & 4 & 13 & 87 & $2-14$ & Faucet & South \\
\hline & 2 & 10 & 3 & 28 & 9 & 4 & 13 & 87 & 2-14 & Faucet & South \\
\hline & 2 & 10 & 3 & 28 & 9 & 4 & 13 & 87 & $2-14$ & Faucet & Tel Aviv \\
\hline & 2 & 10 & 3 & 28 & 9 & 4 & 13 & 87 & $2-14$ & Faucet & South \\
\hline & 2 & 10 & 3 & 28 & 9 & 4 & 13 & 87 & $2-14$ & Water line & Center \\
\hline & 2 & 10 & 3 & 28 & 9 & 4 & 13 & 87 & $2-14$ & Shower & Center \\
\hline & 2 & 10 & 3 & 28 & 9 & 4 & 13 & 87 & $2-14$ & Tap & South \\
\hline & 6 & 10 & 3 & 28 & 19 & 4 & 3 & 2180 & $2-14$ & Hot tub & South \\
\hline & 6 & 10 & 19 & 28 & 19 & 4 & 3 & 292 & $2-14$ & Hot tub & North \\
\hline & 6 & 10 & 19 & 28 & 19 & 4 & 207 & 1409 & $2-14$ & Hot tub & Jerusalem \\
\hline & 2 & 10 & 14 & 10 & 21 & 4 & 3 & 1119 & 1 & Hot tub & South \\
\hline & 6 & 10 & 15 & 12 & 9 & 14 & 11 & 356 & 1 & Cooling tower & Center \\
\hline & 6 & 10 & 15 & 12 & 9 & 14 & 11 & 356 & 1 & Cooling tower & Center \\
\hline & 6 & 10 & 15 & 28 & 4 & 14 & 207 & 1516 & 2-14 & Hot tub & South \\
\hline & 6 & 10 & 15 & 28 & 4 & 14 & 207 & 1516 & 2-14 & Hot tub & South \\
\hline & 6 & 10 & 15 & 28 & 4 & 14 & 207 & 1516 & $2-14$ & Hot tub & South \\
\hline & 6 & 10 & 15 & 28 & 4 & 14 & 207 & 1516 & $2-14$ & Hot tub & South \\
\hline & 6 & 10 & 14 & 28 & 21 & 14 & 9 & 461 & $2-14$ & Storage tank & South \\
\hline & 6 & 10 & 14 & 28 & 21 & 14 & 9 & 461 & $2-14$ & Storage tank & South \\
\hline & 6 & 10 & 14 & 28 & 21 & 14 & 9 & 461 & $2-14$ & Water line & South \\
\hline & 6 & 10 & 14 & 28 & 21 & 14 & 9 & 461 & $2-14$ & Water line & Jerusalem \\
\hline & 3 & 10 & 1 & 28 & 14 & 9 & 207 & 1326 & $2-14$ & Faucet & Jerusalem \\
\hline & 3 & 10 & 1 & 28 & 14 & 9 & 207 & 1326 & $2-14$ & Water line & Jerusalem \\
\hline & 3 & 10 & 1 & 28 & 14 & 9 & 207 & 1326 & $2-14$ & Faucet & Jerusalem \\
\hline & 3 & 10 & 1 & 28 & 14 & 9 & 207 & 1326 & $2-14$ & Shower & Jerusalem \\
\hline & 3 & 10 & 1 & 28 & 14 & 9 & 13 & 93 & $2-14$ & Shower & South \\
\hline & 3 & 10 & 1 & 28 & 14 & 9 & 13 & 93 & 2-14 & Storage tank & Jerusalem \\
\hline & 3 & 10 & 1 & 28 & 14 & 9 & 13 & 93 & $2-14$ & Storage tank & Jerusalem \\
\hline & 3 & 10 & 1 & 28 & 14 & 9 & 13 & 93 & $2-14$ & Hot tub & South \\
\hline & 3 & 10 & 1 & 28 & 14 & 9 & 13 & 93 & $2-14$ & Hot tub & South \\
\hline & 3 & 10 & 1 & 28 & 14 & 9 & 3 & 187 & $2-14$ & Cooling tower & Jerusalem \\
\hline & 3 & 6 & 1 & 28 & 14 & 9 & 3 & 1642 & $2-14$ & Shower & Jerusalem \\
\hline & 3 & 6 & 1 & 28 & 14 & 9 & 3 & 1642 & $2-14$ & Faucet & North \\
\hline & 3 & 6 & 1 & 28 & 14 & 9 & 3 & 1642 & $2-14$ & Faucet & South \\
\hline & 3 & 6 & 1 & 28 & 14 & 9 & 3 & 1642 & $2-14$ & Tap & Tel Aviv \\
\hline & 3 & 6 & 1 & 14 & 14 & 9 & 11 & 40 & 1 & Faucet & Tel Aviv \\
\hline & 1 & 4 & 3 & 1 & 1 & 1 & 60 & 2284 & 1 & Cooling tower & Tel Aviv \\
\hline & 1 & 4 & 3 & 1 & 1 & 1 & 11 & 296 & 1 & Cooling tower & Tel Aviv \\
\hline & 1 & 4 & 3 & 1 & 1 & 1 & 1 & 1 & 1 & Cooling tower & Tel Aviv \\
\hline & 1 & 4 & 3 & 1 & 1 & 1 & 1 & 1 & 1 & Cooling tower & Tel Aviv \\
\hline & 1 & 4 & 3 & 1 & 1 & 1 & 1 & 1 & 1 & Cooling tower & Haifa \\
\hline & 1 & 4 & 3 & 1 & 1 & 1 & 1 & 1 & 1 & Faucet & Center \\
\hline & 1 & 4 & 3 & 1 & 1 & 1 & 1 & 1 & 1 & Cooling tower & South \\
\hline & 1 & 4 & 3 & 1 & 1 & 1 & 1 & 1 & 1 & Cooling tower & Tel Aviv \\
\hline & 1 & 4 & 3 & 1 & 1 & 1 & 1 & 1 & 1 & Faucet & North \\
\hline & 1 & 4 & 3 & 1 & 1 & 1 & 1 & 1 & 1 & Faucet & Tel Aviv \\
\hline & 1 & 4 & 3 & 1 & 1 & 1 & 1 & 1 & 1 & Hot tub & South \\
\hline & 1 & 4 & 3 & 1 & 1 & 1 & 1 & 1 & 1 & Cooling tower & Tel Aviv \\
\hline & 1 & 4 & 3 & 1 & 1 & 1 & 1 & 1 & 1 & Cooling tower & Tel Aviv \\
\hline & 1 & 4 & 3 & 1 & 1 & 1 & 1 & 1 & 1 & Cooling tower & Tel Aviv \\
\hline & 1 & 4 & 3 & 1 & 1 & 1 & 1 & 1 & 1 & Cooling tower & Haifa \\
\hline & 1 & 4 & 3 & 1 & 1 & 1 & 1 & 1 & 1 & Cooling tower & South \\
\hline & 1 & 4 & 3 & 1 & 1 & 1 & 1 & 1 & 1 & Cooling tower & Jerusalem \\
\hline & 1 & 4 & 3 & 1 & 1 & 1 & 1 & 1 & 1 & Cooling tower & Jerusalem \\
\hline & 1 & 4 & 3 & 1 & 1 & 1 & 1 & 1 & 1 & Cooling tower & Jerusalem \\
\hline & 1 & 4 & 3 & 1 & 1 & 1 & 1 & 1 & 1 & Cooling tower & South \\
\hline & 1 & 4 & 3 & 1 & 1 & 1 & 1 & 1 & 1 & Water line & Jerusalem \\
\hline & 1 & 4 & 3 & 1 & 1 & 1 & 1 & 1 & 1 & Hot tub & North \\
\hline & 1 & 4 & 3 & 1 & 14 & 1 & 1 & 286 & 1 & Cooling tower & Haifa \\
\hline & 1 & 6 & 3 & 10 & 1 & 1 & 11 & 284 & 1 & Cooling tower & Haifa \\
\hline & 1 & 6 & 3 & 10 & 1 & 1 & 11 & 284 & 1 & Cooling tower & Haifa \\
\hline & 11 & 14 & 16 & 25 & 7 & 13 & 206 & 1334 & $2-14$ & Cooling tower & South \\
\hline & 11 & 14 & 16 & 25 & 7 & 13 & 206 & 1334 & $2-14$ & Cooling tower & South \\
\hline & 11 & 14 & 16 & 25 & 7 & 13 & 206 & 1334 & $2-14$ & Water line & North \\
\hline & & 14 & 16 & 1 & 7 & 13 & 206 & $*$ & $2-14$ & Cooling tower & Tel Aviv \\
\hline & & 4 & 16 & 1 & 7 & 13 & 206 & $*$ & $2-14$ & Cooling tower & Jerusalem \\
\hline & 5 & 1 & 22 & 30 & 6 & 10 & 213 & 2169 & $2-14$ & Cooling tower & South \\
\hline & 5 & 1 & 22 & 30 & 6 & 10 & 1 & 856 & $2-14$ & Cooling tower & South \\
\hline
\end{tabular}

Figure 2. Similarity dendrogram of 78 L. pneumophila strains isolated from hotel and resort water systems in Israel. A phylogenetic tree was constructed using unweighted pair group method with arithmetic averages (UPGMA) clustering. The sequence type (ST), serogroup, source by category type, and region of isolation are indicated. The asterisks indicate untypeable isolates (failed flaA gene amplification). 
While several L. pneumophila sequence types were distributed widely throughout the country (ST1, ST1642, and ST461), a number of strains have been found to be limited to certain geographical regions. Specifically, ST59, ST1326, and ST1641 were unique to the Jerusalem district, and ST1516 was only found in the Southern region. Moreover, the Southern and Jerusalem districts displayed the most diverse L. pneumophila population, with 11 and 10 different STs, respectively (Figure 3).

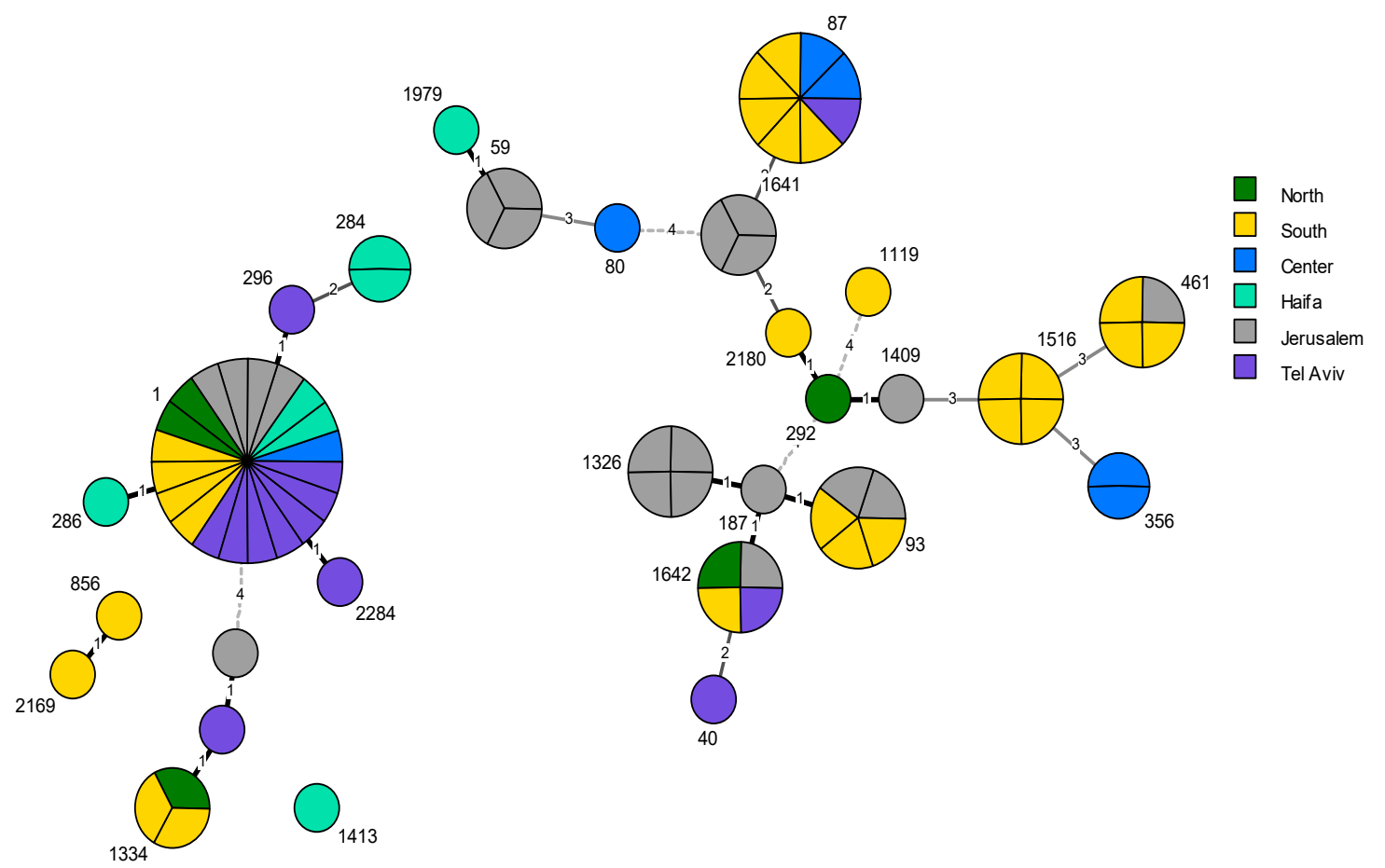

Figure 3. Minimum spanning tree (MST) based on sequence-based typing (SBT) profiles of 78 Lp isolates from hotel and resort water systems. Sequence type (ST) is indicated next to the circles, circle size is proportional to the number of isolates sharing the same ST, and each isolate is shown as a segment of the relevant circle. Branches connect the STs and show the genetic distance between them. STs differing by five or more alleles are not connected. Color-coding of the circles denotes geographic region. Nodes without an ST number represent strains closely related to ST1334 with failed flaA typing.

\section{Discussion}

The abundance of Lp in the tourism sector is a continuous focus of attention in Legionella research, due to its possible implications to public health. A summary of earlier publications reporting national surveys of tourist accommodations in different countries is presented in Table 3.

This study shows, for the first time, the distribution and prevalence of Legionella spp. in the Israeli hotel sector. By analyzing 2830 water specimens, taken from 168 hotels over the two-year period between 2015 and 2017, we demonstrate that $60 \%$ of the examined hotels were colonized with L. pneumophila, and in $37 \%$ of them, the concentrations of Legionella in water exceeded the national regulatory thresholds. Of all 2830 specimens collected, $17 \%$ were Legionella-positive, with half of those exceeding threshold levels of Legionella.

We analyzed the results of Legionella quantitation, according to the category of water source, which included cooling towers, hot tubs, waterlines, showering facilities, storage tanks, and room tap water. The most affected source type was cooling towers $(38 \%)$, while specimens from other sources showed lower rates of Legionella colonization, at around $15 \%$. Furthermore, $32 \%$ of the samples from cooling towers exceeded the $1000 \mathrm{CFU} / \mathrm{L}$ regulatory threshold for Legionella concentrations, making this the water source with the highest proportion of exceeding samples. 
Table 3. Summary of earlier publications reporting national surveys of tourist accommodations in different countries.

\begin{tabular}{|c|c|c|c|c|c|c|c|}
\hline Author & $\begin{array}{l}\text { Country of } \\
\text { Study }\end{array}$ & $\begin{array}{c}\text { Year of } \\
\text { Publication }\end{array}$ & Geography & Sample Selection & Sample Size & Time of Study & Laboratory Methods \\
\hline Borella et al. & Italy & 2005 & $\begin{array}{l}\text { Five representative } \\
\text { cities, northern, } \\
\text { central, and southern } \\
\text { Italian regions }\end{array}$ & $\begin{array}{l}\text { The hotels were selected based on } \\
\text { the water distribution systems in } \\
\text { the cities, the characteristics of the } \\
\text { buildings, and hotel cooperation. }\end{array}$ & $\begin{array}{l}119 \text { water samples } \\
\text { from } 40 \text { hotels }(3-5 \\
\text { samples from each } \\
\text { hotel) }\end{array}$ & $\begin{array}{c}\text { September } \\
\text { 2003-July } 2004\end{array}$ & $\begin{array}{l}\text { Legionella isolation, enumeration and } \\
\text { serotyping; PFGE analysis; physical } \\
\text { and chemical water analyses }\end{array}$ \\
\hline Lee et al. & $\begin{array}{l}\text { South } \\
\text { Korea }\end{array}$ & 2010 & $\begin{array}{l}\text { Seven geographic } \\
\text { regions throughout } \\
\text { South Korea }\end{array}$ & $\begin{array}{l}\text { The number of samples and } \\
\text { isolates depended on the number } \\
\text { of facilities located in each region }\end{array}$ & $\begin{array}{l}\text { 4938 water } \\
\text { samples from } \\
\text { water systems of } \\
\text { different settings, } \\
\text { including hotels. }\end{array}$ & $\begin{array}{l}\text { June-September } \\
2008\end{array}$ & $\begin{array}{l}\text { Legionella isolation, enumeration and } \\
\text { serotyping; molecular identification of } \\
\text { L. spp (16S rRNA, mip, or rpoB); SBT }\end{array}$ \\
\hline Napoli et al. & Italy & 2010 & Southeastern Italy & $\begin{array}{c}\text { Representative samples from } \\
\text { different building types and } \\
\text { water systems. } \\
\text { Re-inspection samples excluded. }\end{array}$ & $\begin{array}{c}13,286 \text { water } \\
\text { samples, including } \\
5009 \text { samples from } \\
305 \text { hotels }\end{array}$ & $\begin{array}{c}\text { January } \\
\text { 2000-December } \\
2009\end{array}$ & $\begin{array}{c}\text { Legionella isolation, enumeration, and } \\
\text { serotyping }\end{array}$ \\
\hline Bonetta et al. & Italy & 2010 & $\begin{array}{l}\text { Northern, central, } \\
\text { and southern Italy }\end{array}$ & $\begin{array}{c}\text { Samples representative of } 18 \\
\text { towns and types of water } \\
\text { systems. }\end{array}$ & $\begin{array}{l}76 \text { water samples } \\
\text { from } 19 \text { hotels }\end{array}$ & $\begin{array}{c}\text { October } \\
\text { 2006-February } \\
2007\end{array}$ & $\begin{array}{l}\text { Legionella isolation, enumeration, and } \\
\text { serotyping; real-time PCR; physical } \\
\text { and chemical analyses }\end{array}$ \\
\hline Chochlakis et al. & Greece & 2013 & $\begin{array}{l}\text { Four regions of Crete } \\
\text { island }\end{array}$ & $\begin{array}{l}\text { Eight to } 15 \text { representative } \\
\text { samples from each hotel, } \\
\text { depending on hotel size and } \\
\text { water system type. }\end{array}$ & $\begin{array}{l}1494 \text { water } \\
\text { samples from } 124 \\
\text { hotels }\end{array}$ & 2004-2011 & $\begin{array}{l}\text { Legionella isolation, enumeration, and } \\
\text { serotyping; molecular identification of } \\
\text { Legionella spp (16S rRNA, mip); } \\
\text { MALDI-TOF mass spectrometry; SBT; }\end{array}$ \\
\hline Sepin Özen et al. & Turkey & 2017 & Antalya region & $\begin{array}{l}\text { Samples from different water } \\
\text { systems }\end{array}$ & $\begin{array}{c}1403 \text { water } \\
\text { samples from } 54 \\
\text { hotels }\end{array}$ & $\begin{array}{l}\text { January-December } \\
2010\end{array}$ & $\begin{array}{c}\text { Legionella isolation, enumeration, and } \\
\text { serotyping }\end{array}$ \\
\hline
\end{tabular}


Cooling towers are the most frequently reported water source of LD outbreaks worldwide [26-28], and can involve a large number of cases $[29,30]$. The role of cooling towers in the urban spread of Lp has also been demonstrated recently in a genomic analysis of isolates over time in Switzerland [31]. The high proportion of Lp-contaminated cooling towers reported here is a public health concern that should prompt further investigation, due to the high population density in urban areas. However, in contrast to the reports from other countries, LD cases in Israel have not been linked to cooling towers. Since not all Legionella spp. and Lp strains are suggested to have the capacity to cause LD [32,33], this might be a reason for the discrepancy. It would be interesting, therefore, to look specifically at the population structure of Legionella spp. in cooling towers nationwide.

Serotyping of a subset of 162 presumed Legionella isolates revealed that 33\% belonged to Lp sg1, while $64 \%$ belonged to Lp sg2-14. Several studies have explored the distribution of Lp sg1 in the environment. A study from South Korea demonstrated the significant predominance of Lp sg1 in manmade water systems, including hotels, with prevalence rates up to 55\% [22]. In Italy, the Lp sg1 distribution rates in the hotel setting differed greatly between two studies, at $27.7 \%$ and $55 \%$, including mixed cultures [15,34]. On the other hand, findings from Italy [19], Greece [23], and Turkey [21] have shown that the most frequent colonizers of the hotel water systems in these studies were Lp sg2-14.

A growing body of evidence shows the Legionella strains' ability for long-term persistence in manmade water systems, without a significant fluctuation of population diversity $[12,35,36]$. Based on this hypothesis, we assume that our findings reflect the rates of Lp sg1 distribution in Israeli hotels, though more investigation is needed to extend our knowledge on the persistence of local Lp strains in water systems associated with different settings.

Using SBT applied on a convenience sample of $78 \mathrm{Lp}$ isolates, we have identified $27 \mathrm{STs}$, including two novel STs. Nine STs belonged to sg1. Lp sg1 ST1 was the prevalent type, accounting for $26 \%$ (20/78) of the sequence-typed isolates.

ST1 has been described by numerous studies, amongst a few other STs, as a main causative agent of LD globally, supporting its high pathogenicity [37,38]. Moreover, in contrast to other highly pathogenic clinical strains rarely isolated from the environment, ST1 has been shown to be among the predominant environmental Lp sg1 strains [22,39-43].

In our study, ST1 comprised 63\% (20/32) of all sg1 isolates from hotel water systems. The high rate of the environmental predominance of Lp sg1 ST1 corresponds with our national surveillance data, where ST1 is by far the most common cause of LD in Israel [44]. This abundance of ST1 in the environment poses a challenge for public health services, limiting their capability to ultimately identify a source of infection during investigations of ST1-associated outbreaks using traditional SBT.

Amongst the non-sg1 isolates (46/78), two isolates failed to generate a full seven-allele profile, due to no amplification of a flaA PCR product. Lp strains with mutations at the SBT flaA primer-binding site have been described elsewhere [45], including an Lp subtype from Israel $(0,14,16,25,7,13,206)$ that had been further identified by the whole genome sequencing (WGS) approach as having the flaA11 allele, and which has been assigned to ST1334 [46]. However, the two strains found in this study differ from ST1334 $(0,4,16,1,7,13,206$ and $0,14,16,1,7,13,206)$, supporting the idea of an ongoing dissemination of the mutation.

Concerning the geographical distribution of the Lp population in this study, we observed a relative abundance of a number of strains in some districts in Israel. For example, sequence type ST1 was identified in each of the six Israeli districts, and ST1642 was found in four of the districts. On the contrary, other subtypes were associated with only one geographical region. For example, ST59, ST1326, and ST1641 were found in the Jerusalem district, and ST1516 was limited to the Southern region. Even though these strains are not unique to Israel, apart from ST1641, we observe their strong association with these two regions from our surveillance programs and during epidemiological investigations [47]. An explanation might be water-related differences between the regions (i.e., physical and chemical properties) caused by the climatic and topographical characteristics of the geographic regions. However, more data is needed to verify this assumption. 
In our study, we have found an unexpectedly low rate of non-Lp spp. in the hotel water systems. In fact, we identified only one L. bozemanii strain from isolates subjected for serotyping. Other studies that have explored the environmental distribution of Legionella spp. have detected Lp and non-Lp co-existence in water. A recent study from the United States has demonstrated that 72 of culture-positive environmental samples collected during summer 2016, where Lp sg1 was recovered, also contained at least one other Lp or non-Lp Legionella spp. [30]. In another study from Crete, Greece [23], carried out from 2004 to 2011, about 50 non-Lp Legionella spp. were identified in the water systems of the hotel setting. Variability in the prevalence of non-Lp spp. between the studies can possibly be explained by the differences in the isolate selection procedure for subsequent analysis. In our study, the initial identification of Legionella spp. was carried out by serotyping, followed by the mip sequencing of non-groupable strains. In contrast, the application of PCR-based techniques for Legionella spp. screening on all samples would probably have yielded results that are more diverse. Moreover, the isolation processing methods used in our study may have reduced the detection of non-pneumophila Legionella spp., due to the overgrowth of other bacteria, and may have underestimated their overall abundance in samples. The membrane plating method is subject to some issues of overgrowth (especially in non-potable water), has been reinforced in a few studies [48,49], and is discussed in the new ISO 11731:2017 [50]. Thus, Legionella spp. distribution may not be fully represented here.

This study has several limitations. First, despite the considerable overall number of 2830 water specimens analyzed, several geographical regions, such as the Northern district, were underrepresented in our study. Second, the study was based on a convenience sample, and thus may not accurately represent the entire tourism sector in Israel, or in certain districts.

In this survey, a large set of water samples was examined routinely without any sampling efforts, due to sporadic travel-associated LD cases or outbreaks. Therefore, our findings on Legionella prevalence in hotel settings in Israel are fully representative of non-outbreak-related surveillance. Regarding the molecular structure of L. pneumophila population, this study demonstrates, for the first time, the molecular profile of Lp strains in the water systems of Israeli hotels and resorts.

Altogether, our findings contribute to the existing knowledge concerning the understanding of the environmental distribution of Legionella spp. in our region, and may facilitate international activities, such as TALD surveillance. The peculiar geographic distribution of different strains should be further investigated.

\section{Materials and Methods}

In total, 2830 convenience samples from 168 hotels and resorts were collected via routine surveillance, according to the regulations of the Israeli Ministry of Health for the prevention of Legionella growth in water distribution systems and hot tubs [51]. The study took place between March 2015 and the end of February 2017 across six Israeli districts (Northern, Center, Southern, Haifa, Tel Aviv, and Jerusalem). Hotels and other tourist accommodation are obliged by the regulations to monitor their water systems for the presence of Legionella spp. The minimum mandatory testing routine schedule depends on the hotel's size: once every two years for sites containing $<50$ rooms, once a year for those with 50-300 rooms, and twice a year for those with $>300$ rooms. Both hot and cold water distribution systems should be tested as part of this procedure. For hot tubs, the minimum sampling routine is quarterly. Selection of the sampling points depends on a hotel water system maintenance plan and is comprised of hot and cold water from outlets representing the rooms (faucets, showers) and mains (hot water return lines, hot and cold water supply, and storage tanks): cold water from cooling towers, decorative fountains, pools, air conditioning systems, and cold/hot/mixed water from hot tubs. Samples were taken after flushing for 2 minutes and the disinfection of the outlet, as per the requirements of the Israeli Public Health guidelines for routine monitoring of water distribution systems [51]. In addition, following regulatory requirements, water systems with Legionella concentrations above the thresholds of $1000 \mathrm{CFU} / \mathrm{L}$ for potable water and $1 \mathrm{CFU} / 100 \mathrm{~mL}$ for hot tubs were re-tested after the appropriate treatment [51]. Overall, of the 168 hotel water systems included 
in this study, 119 were probed at least twice. At each sampling point, 1-2 water samples (hot and/or cold water) were collected in $1 \mathrm{~L}$ sterile plastic bottles containing sodium thiosulfate, in order to neutralize the residual-free chlorine. All water samples were stored at $4{ }^{\circ} \mathrm{C}$ and processed within $24 \mathrm{~h}$ of their collection.

The detection and quantitation of Legionella spp. were performed in a certified water testing laboratory per the ISO 11731-2:2004 method [52]. Potable and non-potable water samples were filtered with $0.45 \mu \mathrm{m}$ sterile gray membrane filter paper, treated with $30 \mathrm{~mL}$ of acid buffer containing $0.2 \mathrm{M}$ KCL and 0.2 M HCL for $5 \mathrm{~min}$, and washed with $20 \mathrm{~mL}$ of PAGE's saline. Water samples originated from cooling towers and fountains were processed in four dilutions (1:10000, 1:1000, 1:100, and 1:10), in order to avoid the overgrowth of microbial flora. Membranes were transferred to Glycine Vancomycin Polymyxin Cycloheximide (GVPC) medium (cat. no. 257007, BD, Heidelberg, Germany) and after incubation at $35 \pm 0.5^{\circ} \mathrm{C}$ for 10 days, colonies suggestive of Legionella spp. were subcultured to Buffered Charcoal Yeast Extract (BCYE) and 5\% sheep blood agar media (P073 and P049, HyLabs, Rehovot, Israel). Subsets of representative isolates identified as Legionella spp. were regularly referred to the National Reference Laboratory for Legionella at the Ministry of Health, according to regulations [51].

The total amount of 164 Legionella isolates from hotel water systems was obtained during the two-year study. Serotyping was performed with the Legionella Latex Test kit (Cat. No. DR0800, Oxoid, Basingstoke, UK).

Strains not readily confirmed by serotyping as L. pneumophila were identified to species level by sequencing the mip gene, as described by Ratcliff et al. [7], and comparing the sequence to the mip database [53]. The molecular characterization of L. pneumophila strains was conducted according to the European Society of Clinical Microbiology and Infectious Diseases (ESCMID) Study Group for Legionella Infections (ESGLI) sequence-based typing (SBT) scheme [54,55]. The choice of the isolates subjected to SBT monthly was based on the data provided by the referring laboratory and guided by epidemiological and risk assessment criteria, such as high Legionella CFU counts, a source type with high public health risk potential, or a new sampling site. After the exclusion of duplicate isolates arising from the same sampling points, 78 isolates were examined in this study. Sequences obtained by Sanger sequencing were analyzed with the BioNumerics software (Version 7.6, Applied Maths) and compared to the ESGLI database for assigning the ST. New allelic profiles were submitted to the ESGLI SBT database [56]. The strain diversity index was calculated according to the modified method of Hunter and Gaston [57].

BioNumerics software (Version 7.6, Applied Maths) was used for phylogenetic analysis. Clustering was created using the unweighted pair group method with arithmetic averages (UPGMA) [58]. The minimum spanning tree (MST) was created using a predefined MST for the categorical data template, with single- and double-locus variance priority rules. Geomap was created using ArcGIS Pro 2.5 (Esri, Redlands, CA, USA).

Author Contributions: Conceptualization, J.M.-G.; methodology, E.Y. and J.M.-G.; formal analysis, L.V. and E.K.; investigation, E.K.; resources, V.A. and I.G.; data curation, E.Y. and E.K.; writing一original draft preparation, E.Y.; writing-review and editing, J.M.-G. and L.V.; supervision, L.V.; funding acquisition, V.A. and I.G. All authors have read and agreed to the published version of the manuscript.

Funding: This research received no external funding.

Conflicts of Interest: The authors declare no conflict of interest.

\section{References}

1. Fields, B.S.; Benson, R.F.; Besser, R.E. Legionella and Legionnaires' disease: 25 years of investigation. Clin. Microbiol. Rev. 2002, 15, 506-526. [CrossRef] [PubMed]

2. Oliva, G.; Sahr, T.; Buchrieser, C. The Life Cycle of L. pneumophila: Cellular Differentiation Is Linked to Virulence and Metabolism. Front. Cell. Infect. Microbiol. 2018, 8, 3. [CrossRef] [PubMed] 
3. McDade, J.E.; Shepard, C.C.; Fraser, D.W.; Tsai, T.R.; Redus, M.A.; Dowdle, W.R. Legionnaires' disease: Isolation of a bacterium and demonstration of its role in other respiratory disease. N. Engl. J. Med. 1977, 297, 1197-1203. [CrossRef] [PubMed]

4. Phin, N.; Parry-Ford, F.; Harrison, T.; Stagg, H.R.; Zhang, N.; Kumar, K.; Lortholary, O.; Zumla, A.; Abubakar, I. Epidemiology and clinical management of Legionnaires' disease. Lancet Infect. Dis. 2014, 14, 1011-1021. [CrossRef]

5. Khodr, A.; Kay, E.; Gomez-Valero, L.; Ginevra, C.; Doublet, P.; Buchrieser, C.; Jarraud, S. Molecular epidemiology, phylogeny and evolution of Legionella. Infect. Genet. Evol. 2016, 43, 108-122. [CrossRef]

6. Burillo, A.; Pedro-Botet, M.L.; Bouza, E. Microbiology and Epidemiology of Legionnaire's Disease. Infect. Dis. Clin. N. Am. 2017, 31,7-27. [CrossRef]

7. Ratcliff, R.M.; Lanser, J.A.; Manning, P.A.; Heuzenroeder, M.W. Sequence-based classification scheme for the genus Legionella targeting the mip gene. J. Clin. Microbiol. 1998, 36, 1560-1567. [CrossRef]

8. Yu, V.L.; Plouffe, J.F.; Pastoris, M.C.; Stout, J.E.; Schousboe, M.; Widmer, A.; Summersgill, J.; File, T.; Heath, C.M.; Paterson, D.L.; et al. Distribution of Legionella species and serogroups isolated by culture in patients with sporadic community-acquired legionellosis: An international collaborative survey. J. Infect. Dis. 2002, 186, 127-128. [CrossRef]

9. Bartram, J.; Chartier, Y.; Lee, J.V.; Pond, K.; Surman-Lee, S. Legionella and the Prevention of Legionellosis; World Health Organization: Geneva, Switzerland, 2007.

10. ECDC. Legionnaires' Disease-Annual Epidemiological Report for 2015. Available online: https://www.ecdc. europa.eu/sites/portal/files/documents/AER_for_2015-legionnaires-disease_0.pdf (accessed on 21 November 2017).

11. Smith, S.S.; Ritger, K.; Samala, U.; Black, S.R.; Okodua, M.; Miller, L.; Kozak-Muiznieks, N.A.; Hicks, L.A.; Steinheimer, C.; Ewaidah, S.; et al. Legionellosis Outbreak Associated With a Hotel Fountain. Open Forum Infect. Dis. 2015, 2, ofv164. [CrossRef]

12. Ahlen, C.; Aas, M.; Krusnell, J.; Iversen, O.J. A single Legionella pneumophila genotype in the freshwater system in a ship experiencing three separate outbreaks of legionellosis in 6 years. Microb. Ecol. Health Dis. 2016, 27, 31148.

13. Sánchez-Busó, L.; Guiral, S.; Crespi, S.; Moya, V.; Camaró, M.L.; Olmos, M.P.; Adrián, F.; Morera, V.; González-Morán, F.; Vanaclocha, H.; et al. Genomic Investigation of a Legionellosis Outbreak in a Persistently Colonized Hotel. Front. Microbiol. 2016, 6, 1556. [CrossRef] [PubMed]

14. Chochlakis, D.; Sandalakis, V.; Keramarou, M.; Tselentis, Y.; Psaroulaki, A. Legionellosis: A Walk-through to Identification of the Source of Infection. Cent. Eur. J. Public Health 2017, 25, 235-239. [CrossRef] [PubMed]

15. Borella, P.; Montagna, M.T.; Stampi, S.; Stancanelli, G.; Romano-Spica, V.; Triassi, M.; Marchesi, I.; Bargellini, A.; Tato, D.; Napoli, C.; et al. Legionella Contamination in Hot Water of Italian Hotels. Appl. Environ. Microbiol. 2005, 71, 5805-5813. [CrossRef] [PubMed]

16. Leoni, E.; De Luca, G.; Legnani, P.P.; Sacchetti, R.; Stampi, S.; Zanetti, F. Legionella waterline colonization: Detection of Legionella species in domestic, hotel and hospital hot water systems. J. Appl. Microbiol. 2005, 98, 373-379. [CrossRef]

17. Mouchtouri, V.A.; Rudge, J.W. Legionnaires' Disease in Hotels and Passenger Ships: A Systematic Review of Evidence, Sources, and Contributing Factors. J. Travel Med. 2015, 22, 325-337. [CrossRef]

18. Mouchtouri, V.; Velonakis, E.; Tsakalof, A.; Kapoula, C.; Goutziana, G.; Vatopoulos, A.; Kremastinou, J.; Hadjichristodoulou, C. Risk Factors for Contamination of Hotel Water Distribution Systems by Legionella Species. Appl. Environ. Microbiol. 2007, 73, 1489-1492. [CrossRef]

19. Bonetta, S.; Bonetta, S.; Ferretti, E.; Balocco, F.; Carraro, E. Evaluation ofLegionella pneumophila contamination in Italian hotel water systems by quantitative real-time PCR and culture methods. J. Appl. Microbiol. 2010, 108, 1576-1583. [CrossRef]

20. Fragou, K.; Kokkinos, P.; Gogos, C.; Alamanos, Y.; Vantarakis, A. Prevalence of Legionella spp. in water systems of hospitals and hotels in South Western Greece. Int. J. Environ. Health Res. 2012, 22, 340-354. [CrossRef]

21. Sepin Özen, N.; Tuğlu Ataman, Ş.; Emek, M. Exploring the Legionella pneumophila positivity rate in hotel water samples from Antalya, Turkey. Environ. Sci. Pollut. Res. 2017, 24, 12238-12242. [CrossRef] 
22. Lee, H.K.; Shim, J.I.; Kim, H.E.; Yu, J.Y.; Kang, Y.H. Distribution of Legionella Species from Environmental Water Sources of Public Facilities and Genetic Diversity of L. pneumophila Serogroup 1 in South Korea. Appl. Environ. Microbiol. 2010, 76, 6547-6554. [CrossRef]

23. Chochlakis, D.; Sandalakis, V.; Panoulis, C.; Goniotakis, I.; Makridaki, E.; Tselentis, Y.; Psaroulaki, A. Typing ofLegionella strains isolated from environmental samples in Crete, Greece, during the period 2004-2011. J. Water Health 2013, 11, 762. [CrossRef] [PubMed]

24. Katsiaflaka, A.; Pournaras, S.; Kristo, I.; Mouchtouri, V.A.; Kyritsi, M.; Velonakis, E.; Vatopoulos, A.C.; Hadjichristodoulou, C. Epidemiological Investigation of Legionella pneumophila Serogroup 2 to 14 Isolates from Water Samples by Amplified Fragment Length Polymorphism and Sequence-Based Typing and Detection of Virulence Traits. Appl. Environ. Microbiol. 2016, 82, 6102-6108. [CrossRef] [PubMed]

25. Moran-Gilad, J.; Mentasti, M.; Lazarovitch, T.; Huberman, Z.; Stocki, T.; Sadik, C.; Shahar, T.; Anis, E.; Valinsky, L.; Harrison, T.G.; et al. Molecular epidemiology of Legionnaires' disease in Israel. Clin. Microbiol. Infect. 2014, 20, 690-696. [CrossRef] [PubMed]

26. Weiss, D.; Boyd, C.; Rakeman, J.L.; Greene, S.K.; Fitzhenry, R.; McProud, T.; Musser, K.; Huang, L.; Kornblum, J.; Nazarian, E.J.; et al. A Large Community Outbreak of Legionnaires' Disease Associated With a Cooling Tower in New York City, 2015. Public Health Rep. 2017, 132, 241-250. [CrossRef]

27. Fitzhenry, R.; Weiss, D.; Cimini, D.; Balter, S.; Boyd, C.; Alleyne, L.; Stewart, R.; McIntosh, N.; Econome, A.; Lin, Y.; et al. Legionnaires' Disease Outbreaks and Cooling Towers, New York City, New York, USA. Emerg. Infect. Dis. 2017, 23, 1769. [CrossRef]

28. Petzold, M.; Ehricht, R.; Slickers, P.; Pleischl, S.; Brockmann, A.; Exner, M.; Monecke, S.; Luck, C. Rapid genotyping of Legionella pneumophila serogroup 1 strains by a novel DNA microarray-based assay during the outbreak investigation in Warstein, Germany 2013. Int. J. Hyg. Environ. Health 2017, 220, 673-678. [CrossRef]

29. Bassett, M.T.; Balter, S. Regulating Cooling Towers to Prevent Outbreaks of Legionnaires' Disease. Public Health Rep. 2017, 132, 133-135. [CrossRef]

30. Llewellyn, A.C.; Lin, B.; Lucas, C.E.; Roberts, S.E.; Brown, E.W.; Nayak, B.S.; Raphael, B.H.; Winchell, J.M. Distribution of Legionella and bacterial community composition among regionally diverse US cooling towers. PLOS ONE 2017, 12, e0189937. [CrossRef]

31. Wuthrich, D.; Gautsch, S.; Spieler-Denz, R.; Dubuis, O.; Gaia, V.; Moran-Gilad, J.; Hinic, V.; Seth-Smith, H.M.; Nickel, C.H.; Tschudin-Sutter, S.; et al. Air-conditioner cooling towers as complex reservoirs and continuous source of Legionella pneumophila infection evidenced by a genomic analysis study in 2017, Switzerland. Eur. Commun. Dis. Bull. 2019, 24, 1800192. [CrossRef]

32. Amemura-Maekawa, J.; Kikukawa, K.; Helbig, J.H.; Kaneko, S.; Suzuki-Hashimoto, A.; Furuhata, K.; Chang, B.; Murai, M.; Ichinose, M.; Ohnishi, M.; et al. Distribution of monoclonal antibody subgroups and sequence-based types among Legionella pneumophila serogroup 1 isolates derived from cooling tower water, bathwater, and soil in Japan. Appl. Environ. Microbiol. 2012, 78, 4263-4270. [CrossRef]

33. Lawrence, A.; Eglezos, S.; Huston, W. Environmental Legionella spp. collected in urban test sites of South East Queensland, Australia, are virulent to human macrophages in vitro. Res. Microbiol. 2016, 167, 149-153. [CrossRef] [PubMed]

34. Napoli, C.; Fasano, F.; Iatta, R.; Barbuti, G.; Cuna, T.; Montagna, M.T. Legionella spp. and legionellosis in southeastern Italy: Disease epidemiology and environmental surveillance in community and health care facilities. BMC Public Health 2010, 10, 660. [CrossRef] [PubMed]

35. Perola, O.; Kauppinen, J.; Kusnetsov, J.; Karkkainen, U.M.; Luck, P.C.; Katila, M.L. Persistent Legionella pneumophila colonization of a hospital water supply: Efficacy of control methods and a molecular epidemiological analysis. APMIS 2005, 113, 45-53. [CrossRef] [PubMed]

36. Cooper, I.R.; White, J.; Mahenthiralingam, E.; Hanlon, G.W. Long-term persistence of a single Legionella pneumophila strain possessing the mip gene in a municipal shower despite repeated cycles of chlorination. J. Hosp. Infect. 2008, 70, 154-159. [CrossRef]

37. Vekens, E.; Soetens, O.; De Mendonca, R.; Echahidi, F.; Roisin, S.; Deplano, A.; Eeckhout, L.; Achtergael, W.; Pierard, D.; Denis, O.; et al. Sequence-based typing of Legionella pneumophila serogroup 1 clinical isolates from Belgium between 2000 and 2010. Eurosurveillance 2012, 17, 20302. 
38. David, S.; Rusniok, C.; Mentasti, M.; Gomez-Valero, L.; Harris, S.R.; Lechat, P.; Lees, J.; Ginevra, C.; Glaser, P.; $\mathrm{Ma}, \mathrm{L}$.; et al. Multiple major disease-associated clones of Legionella pneumophila have emerged recently and independently. Genome Res. 2016, 26, 1555-1564. [CrossRef]

39. Qin, T.; Zhou, H.; Ren, H.; Guan, H.; Li, M.; Zhu, B.; Shao, Z. Distribution of sequence-based types of legionella pneumophila serogroup 1 strains isolated from cooling towers, hot springs, and potable water systems in China. Appl. Environ. Microbiol. 2014, 80, 2150-2157. [CrossRef]

40. Lévesque, S.; Lalancette, C.; Bernard, K.; Pacheco, A.L.; Dion, R.; Longtin, J.; Tremblay, C. Molecular Typing of Legionella pneumophila Isolates in the Province of Quebec from 2005 to 2015. PLoS ONE 2016, 11, e0163818. [CrossRef]

41. Kozak-Muiznieks, N.A.; Lucas, C.E.; Brown, E.; Pondo, T.; Taylor, T.H., Jr.; Frace, M.; Miskowski, D.; Winchell, J.M. Prevalence of sequence types among clinical and environmental isolates of Legionella pneumophila serogroup 1 in the United States from 1982 to 2012. J. Clin. Microbiol. 2014, 52, 201-211. [CrossRef]

42. Sanchez-Buso, L.; Coscolla, M.; Palero, F.; Camaro, M.L.; Gimeno, A.; Moreno, P.; Escribano, I.; Lopez Perezagua, M.M.; Colomina, J.; Vanaclocha, H.; et al. Geographical and Temporal Structures of Legionella pneumophila Sequence Types in Comunitat Valenciana (Spain), 1998 to 2013. Appl. Environ. Microbiol. 2015, 81, 7106-7113. [CrossRef]

43. Quero, S.; Parraga-Nino, N.; Barrabeig, I.; Sala, M.R.; Pedro-Botet, M.L.; Monso, E.; Jane, M.; Sabria, M.; Garcia-Nunez, M. Population structure of Environmental and Clinical Legionella pneumophila isolates in Catalonia. Sci. Rep. 2018, 8, 6241. [CrossRef] [PubMed]

44. Ministry of Health Central Laboratories Annual Report, pp. 66-67. Available online: https://www.health.gov. il/PublicationsFiles/LAB_JER2017.pdf (accessed on 25 May 2020).

45. Harrison, T.G.; Moran-Gilad, J.; Mentasti, M.; David, S.; Afshar, B.; Andersen, P.S.; Stegger, M.; Valinsky, L.; Yakunin, E.; Uldum, S.A. Use of whole genome sequence (WGS) data to investigate anomalies in the ESGLI Legionella pneumophila DNA-sequence based typing (SBT) method. In Proceedings of the 2nd ESCMID Study Group for Legionella Infections Meeting (ESGLI), Barcelona, Spain, 17-19 September 2014.

46. Qadreyah Al-Matawah, S.A.-Z. Søren Uldum Sequence-Based Typing for Legionella Pneumophila Isolated from Water Systems of Residential Facilities in Kuwait. J. Environ. Sci. 2016, 2, 016.

47. Yakunin, E.; Ohayon, S.; Schnaidman, B.; Marva, E.; Agmon, V.; Eizenkraft, A.; Wagnert, L.; Grotto, I.; Valinsky, L.; Moran-Gilad, J. Prevalence and Diversity of Legionella pneumophila in the Defence Setting. In Proceedings of the Israeli Society for Microbiology Annual Meeting, Beit Dagan, Israel, 13-14 September 2017.

48. Leoni, E.; Legnani, P.P. Comparison of selective procedures for isolation and enumeration of Legionella species from hot water systems. J. Appl. Microbiol. 2001, 90, 27-33. [CrossRef] [PubMed]

49. Kirschner, A.K.T. Determination of viable legionellae in engineered water systems: Do we find what we are looking for? Water Res. 2016, 93, 276-288. [CrossRef]

50. International Organization for Standardization. Water Quality_Enumeration of Legionella; ISO 11731:2017; ISO: Geneva, Switzerland, 2017.

51. Guidelines on Preventing the Proliferation of the Legionella Bacteria in Water Systems. Available online: https://www.health.gov.il/Subjects/Environmental_Health/drinking_water/Pages/Legionella.aspx (accessed on 25 May 2020).

52. International Organization for Standardization. Water Quality-Detection and Enumeration of Legionella-Part 2: Direct Membrane Filtration method for Waters with Low Bacterial Counts; ISO 11731-2:2004; ISO: Geneva, Switzerland, 2004.

53. Public Health England. mip Sequencing Database. Available online: https://www.gov.uk/guidance/phedata-and-analysis-tools (accessed on 19 November 2018).

54. Gaia, V.; Fry, N.K.; Afshar, B.; Luck, P.C.; Meugnier, H.; Etienne, J.; Peduzzi, R.; Harrison, T.G. Consensus sequence-based scheme for epidemiological typing of clinical and environmental isolates of Legionella pneumophila. J. Clin. Microbiol. 2005, 43, 2047-2052. [CrossRef]

55. Ratzow, S.; Gaia, V.; Helbig, J.H.; Fry, N.K.; Luck, P.C. Addition of neuA, the gene encoding N-acylneuraminate cytidylyl transferase, increases the discriminatory ability of the consensus sequence-based scheme for typing Legionella pneumophila serogroup 1 strains. J. Clin. Microbiol. 2007, 45, 1965-1968. [CrossRef] 
56. Public Health England. L. pneumophila Sequenced-Based Typing. Available online: https: //webarchive.nationalarchives.gov.uk/20190501130700/http://bioinformatics.phe.org.uk/legionella/ legionella_sbt/php/sbt_homepage.php (accessed on 20 November 2019).

57. Hunter, P.R.; Gaston, M.A. Numerical index of the discriminatory ability of typing systems: An application of Simpson's index of diversity. J. Clin. Microbiol. 1988, 26, 2465-2466. [CrossRef]

58. Sokal, R.R.; Michener, C.D. A statistical method for evaluating systematic relationships. Univ. Kans. Sci. Bull. 1958, 38, 1409-1438.

(C) 2020 by the authors. Licensee MDPI, Basel, Switzerland. This article is an open access article distributed under the terms and conditions of the Creative Commons Attribution (CC BY) license (http://creativecommons.org/licenses/by/4.0/). 